\title{
Exploring the nitrous acid (HONO) formation mechanism in winter Beijing: direct emissions and heterogeneous production in urban and suburban areas $\uparrow$
}

\author{
Shengrui Tong, t $^{* a}$ Siqi Hou, $\star^{a}$ Ying Zhang, ${ }^{a}$ Biwu Chu, ${ }^{b}$ Yongchun Liu, ${ }^{b}$ \\ Hong $\mathrm{He}^{\mathrm{b}}$ Pusheng Zhao ${ }^{c}$ and Maofa Ge*a
}

Received 13th November 2015, Accepted 11th December 2015

DOI: $10.1039 / c 5 f d 00163 c$

Continuous measurements of nitrous acid ( $\mathrm{HONO}$ ) were performed from December 12 to December 22, 2015 in both urban and suburban areas of Beijing to study the formation mechanism of HONO. The measurement campaign in both sites included a cleanhaze-clean transformation process. HONO concentrations showed similar variations in the two sites, while they were always higher in the urban area. Moreover, correlations of HONO with $\mathrm{NO}_{x}, \mathrm{NO}_{2}, \mathrm{NO}, \mathrm{PM}_{2.5}$ and relative humidity $(\mathrm{RH})$ were studied to explore possible HONO formation pathways, and the contributions of direct emissions, heterogeneous reactions, and homogeneous reactions were also calculated. This showed that HONO in urban and suburban areas underwent totally different formation procedures, which were affected by meteorological conditions, $\mathrm{PM}_{2.5}$ concentrations, direct emissions, homogeneous reactions and heterogeneous reactions. $\mathrm{PM}_{2.5}$ concentrations and $\mathrm{RH}$ would influence the $\mathrm{NO}_{2}$ conversion efficiency. Heterogeneous reactions of $\mathrm{NO}_{2}$ were more efficient in suburban areas and in clean periods while direct emissions and homogeneous reactions contributed more in urban areas and in polluted periods when the concentrations of $\mathrm{NO}_{x}$ and $\mathrm{NO}$ were at a high level.

\section{Introduction}

Nitrous acid (HONO) plays an essential role in photochemical cycles by providing hydroxyl radicals $(\mathrm{OH})$, with contributions of $30-50 \%$ of $\mathrm{OH}$ during the daytime. ${ }^{1-5}$ The $\mathrm{OH}$ radical, as one of the most important oxidants in the

${ }^{a}$ State Key Laboratory for Structural Chemistry of Unstable and Stable Species, Beijing National Laboratory for Molecular Sciences (BNLMS), Institute of Chemistry, Chinese Academy of Sciences, Beijing, 100190, P. R. China.E-mail: tongsr@iccas.ac.cn; gemaofa@iccas.ac.cn

${ }^{b}$ Research Center for Eco-Environmental Sciences, Chinese Academy of Sciences, Beijing, 100085, P. R. China ${ }^{\prime}$ Institute of Urban Meteorology, China Meteorological Administration, Beijing, 100089, P. R. China

$\dagger$ Electronic supplementary information (ESI) available. See DOI: 10.1039/c5fd00163c

\$ Shengrui Tong and Siqi Hou contributed equally to this work. 


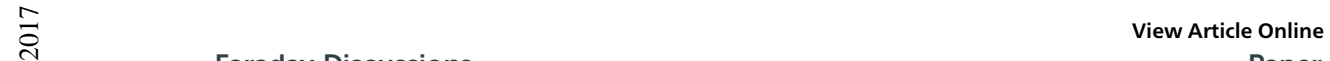

atmosphere, dominates the oxidation capacity in the troposphere by reacting with organic matter, leading to the formation of secondary pollutants and accelerating the formation of air pollution. ${ }^{5-7}$

The commonly accepted sources of HONO are direct emissions, homogeneous reactions and heterogeneous formations.$^{8-10}$ Studies by Kurtenbach ${ }^{11}$ and Kirchstetter et $a l .{ }^{12}$ have recognized that HONO could be emitted by combustion processes and traffic emissions with quantities of about $0.3-0.8 \%$ of $\mathrm{NO}_{x}(\mathrm{NO}+$ $\mathrm{NO}_{2}$ ) obtained by tunnel studies. Homogeneous reaction between $\mathrm{NO}$ and $\mathrm{OH}$ can produce HONO, though this reaction was thought to be less important due to the low concentrations of $\mathrm{OH}$ radicals at night. ${ }^{10}$ However, recent studies have strengthened the importance of this reaction source in polluted regions with high $\mathrm{OH}$ and NO concentrations.

Compared to the two sources mentioned above, the kinetics and mechanisms of HONO from heterogeneous reactions still remain unclear. ${ }^{2,8,13}$ Studies have suggested HONO could be formed by $\mathrm{NO}_{2}$ on wet surfaces, ${ }^{14-16}$ and kinetics data showed the reaction is first order in $\mathrm{NO}_{2}$ and dependent on surface water. ${ }^{14,17,18}$ The hydrolysis of $\mathrm{NO}_{2}$ could happen on various surfaces including ground, buildings and vegetation surfaces. ${ }^{14}$ In addition, HONO could be formed by $\mathrm{NO}_{2}$ reduction on the surface of soot and other aerosols, especially under sunlight. ${ }^{13,16,19,20}$ However, the contribution of this reaction to the HONO budget is still in debate due to the rather small aerosol surfaces and the slow reaction rate. ${ }^{9,21}$

The effects of HONO have gained great attention due to the more and more frequent pollution events occurring in China recently. ${ }^{8}$ Observations of HONO have been documented at many sites including Beijing, ${ }^{22,23}$ Guangzhou ${ }^{8,24,25}$ and Shanghai. ${ }^{26}$ Results showed HONO concentrations were much higher in mega cities with heavy pollution than in remote places and clean areas. However, studies are still lacking, especially those focused on comparisons of HONO evolution between urban and suburban areas, and between haze and non-haze periods. The chemical reactions during haze episodes provide complicated interactions of HONO with other chemical species, which will be helpful to understand the formation and removal mechanisms of HONO.

In this study, a continuous measurement was performed in the urban and suburban areas of Beijing in December of 2014, when both urban and suburban areas suffered typical haze episodes and a following non-haze period. The evolution of $\mathrm{HONO}$ and other related gas pollutants like $\mathrm{NO}, \mathrm{NO}_{2}, \mathrm{NO}_{x}, \mathrm{O}_{3}, \mathrm{SO}_{2}$ and $\mathrm{CO}$ was explored under changing meteorological conditions. Moreover, in order to investigate the impact factors of HONO, differences were compared between haze and non-haze periods of both urban and suburban sites. Finally, the influences of different HONO sources including direct emissions, homogeneous reactions and heterogeneous formation in both sites were discussed and formation mechanisms were analyzed in detail.

\section{Experimental}

\section{Measurement instruments}

HONO concentrations were measured by a home-made HONO analyzer, which has been used in several measurements previously. ${ }^{27,28}$ The principle of the homemade HONO analyzer is introduced briefly: HONO was absorbed by a specific 
solution (0.06 $\mathrm{M}$ sulfanilamide in $1 \mathrm{M} \mathrm{HCl})^{5,29,30}$ in a glass device with a twochannel stripping coil. The absorption solution from two channels was pumped by a peristaltic pump to react with a dye solution [0.8 $\mathrm{mM} N$-(1-naphthyl) ethylene diamine dihydrochloride $]^{31}$ to form the azo dye and then detected by a minispectrometer using a diode array detector (Ocean Optics, SD2000). The true HONO concentrations could be obtained by subtracting the calibrated signal of the second coil from the first coil. ${ }^{29,31}$ Comparison between the HONO analyzer and Long Path Absorption (LOPAP) yielded excellent agreements.

Gas phase pollutants of $\mathrm{CO}, \mathrm{SO}_{2}, \mathrm{O}_{3}, \mathrm{NO}, \mathrm{NO}_{2}$ and $\mathrm{NO}_{x}$ were measured by commercial Thermo scientific analyzers: $\mathrm{SO}_{2}$ analyzer (43i), $\mathrm{O}_{3}$ analyzer (49i), $\mathrm{NO}_{x}$ analyzer (42i) and CO analyzer (48i) with detection limits of 1 ppbv, 1 ppbv, 1 ppbv and 0.05 ppmv, respectively.

\section{Measurement site}

The measurements were performed from 12 to 22 December in both urban and suburban areas in Beijing. The measurement sites were described in detail in a previous study. ${ }^{28}$ The locations of the measurement sites are shown in Fig. 1. Here is a brief description.

Urban site (ICCAS): HONO concentrations were measured in No. 2 building of the Institute of Chemistry, Chinese Academy of Sciences (ICCAS, $116^{\circ} 19^{\prime} 21.58^{\prime \prime} \mathrm{E}$, $39^{\circ} 59^{\prime} 22.68^{\prime \prime} \mathrm{N}$ ). Concentrations of other gaseous species were measured at Baolian, 5.5 kilometers southwest of the ICCAS site. Both of the two measurement sites are located at the North Fourth Ring Road of HaiDian District with similar conditions, which are surrounded by dense population and heavy traffic. Meteorological parameters, including wind speed, wind direction, temperature, pressure, relative humidity and $\mathrm{PM}_{2.5}$ concentrations were all obtained from Baolian station.

Suburban site: the HONO analyzer and other gas analyzers were set in the Lake Yanqi campus of the University of Chinese academy of sciences (UCAS, $40.4^{\circ} \mathrm{N}$, $\left.116.6^{\circ} \mathrm{E}\right)$. Concentrations of $\mathrm{PM}_{2.5}$ and meteorological parameters were also

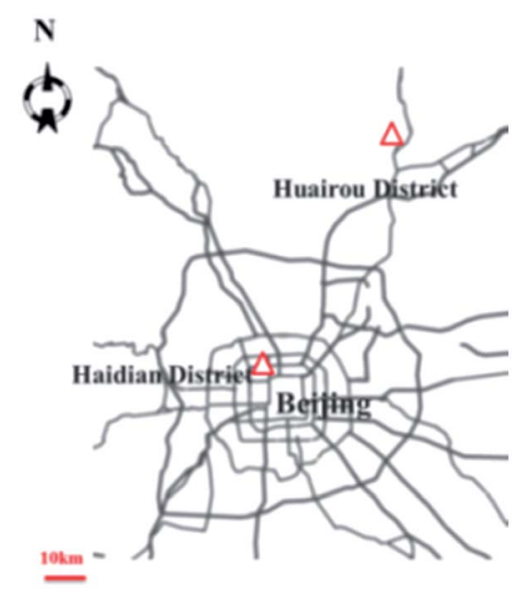

Fig. 1 The locations of the measurement sites. 
obtained there. This site is a typical suburban representative, which is $50 \mathrm{~km}$ northeast of the city center. In addition, the environmental conditions at this site are more diverse due to being surrounding by a highway on the west side, a lake to the northeast, farm lands nearby and a railway station within 1.1 kilometers.

\section{Results and discussion}

\section{Overview of the observation}

Temporal variations of meteorological data and measured chemical species. $\mathrm{PM}_{2.5}$ concentrations and the measured meteorological parameters of air temperature $(T)$, relative humidity (RH), wind speed (WS) and direction (WD) are illustrated in Fig. 2. It can be seen from the plot that there were two increases of $\mathrm{PM}_{2.5}$ concentration for both urban and suburban areas during the measurement campaign. Therefore, two groups were divided based on $\mathrm{PM}_{2.5}$ concentrations (Table 1): haze period, when $\mathrm{PM}_{2.5}$ concentrations were higher than $75 \mu \mathrm{g} \mathrm{m}^{-3}$; and non-haze period, when $\mathrm{PM}_{2.5}$ concentrations were lower than $75 \mu \mathrm{g} \mathrm{m}^{-3}$. In detail, the haze period was from 8:00 of Dec 13 to 7:00 of Dec 15 and from 22:00 of Dec 16 to 8:00 of Dec 19. While the non-haze period was the remaining time. In addition, data with wind speed higher than $2.0 \mathrm{~m} \mathrm{~s}^{-1}$ were excluded from our discussion.

During the non-haze period, the average $\mathrm{PM}_{2.5}$ concentrations of the urban and suburban sites were 29.0 and $23.1 \mu \mathrm{g} \mathrm{m}{ }^{-3}$, respectively. Such a low $\mathrm{PM}_{2.5}$ concentration was due to the blowing wind with a mean speed of 3.1 and $1.5 \mathrm{~m}$ $\mathrm{s}^{-1}$, respectively, which also caused a low temperature range in both observation sites. The average temperature during this period was -1.4 and $-2.1{ }^{\circ} \mathrm{C}$ and the relative humidity was $24.9 \%$ and $25.7 \%$, respectively. During the haze period, the

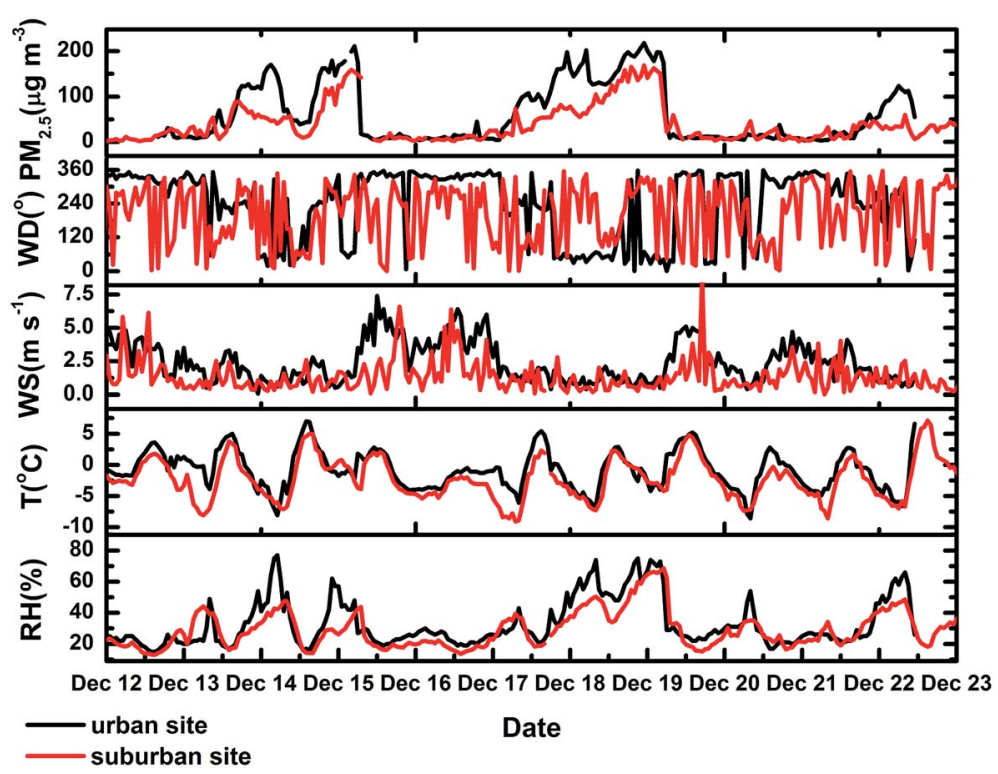

Fig. 2 Hourly-averaged air temperature (T), relative humidity $(\mathrm{RH})$, wind speed (WS), wind direction (WD) and PM 2.5 concentrations during Dec 12 to Dec 22, 2014. 
Table 1 Classification of meteorological conditions during Dec 12 to Dec 22, 2014

\begin{tabular}{llllllll}
\hline Location & $\begin{array}{l}\text { Time } \\
\text { period }\end{array}$ & $\begin{array}{l}\text { Weather } \\
\text { condition }\end{array}$ & $\begin{array}{l}\mathrm{PM}_{2.5} \text { concentration } \\
\left(\mu \mathrm{g} \mathrm{m}^{-3}\right)\end{array}$ & $\begin{array}{l}T \\
\left({ }^{\circ} \mathrm{C}\right)\end{array}$ & $\begin{array}{l}\mathrm{RH} \\
(\%)\end{array}$ & $\begin{array}{l}\text { WS } \\
\left(\mathrm{m} \mathrm{s}^{-1}\right)\end{array}$ & WD \\
\hline Urban & $\begin{array}{l}\text { Dec 14-15; } \\
\text { Dec 18-19 }\end{array}$ & Haze & 144.0 & -1.1 & 50.0 & 1.1 & Northeast \\
& $\begin{array}{l}\text { Dec 12-13; } \\
\text { Dec 20-22 }\end{array}$ & Non-haze & 29.0 & -1.34 & 24.9 & 3.1 & North \\
Suburban & $\begin{array}{l}\text { Dec 14-15; } \\
\text { Dec 18-19 } \\
\text { Dec 12-13; }\end{array}$ & Haze & 104.8 & -0.5 & 40.8 & 0.9 & North \\
& & & -2.1 & 25.7 & 1.5 & $\begin{array}{l}\text { No certain } \\
\text { Dec 20-22 }\end{array}$ \\
& & 21.1 & & & & directions
\end{tabular}

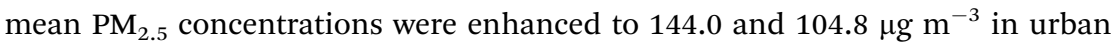
and suburban sites, with $\mathrm{RH}$ increasing to 50.0 and $40.8 \%$, respectively. In addition, the wind speed during this period went down to 1.1 and $0.8 \mathrm{~m} \mathrm{~s}^{-1}$ on average. Variation tendencies of $\mathrm{PM}_{2.5}$ concentrations and meteorological parameters in both haze and non-haze periods at the two observation sites were similar except the wind speeds and wind directions, which were mainly due to the geographical location differences.

Fig. 3 shows the variation of gas species measured during the observation campaign in the urban site and suburban site. Average concentrations of gasphase species are shown in Fig. 4. The average values of HONO concentrations at the urban and suburban sites were comparable to our previous measurements at the same observation sites in October of $2014 .^{28}$ Moreover, they were also in accordance with measurements by Spataro et al. ${ }^{22}$ (HONO concentration was 1.06 ppbv on average with $\mathrm{NO}_{2}$ of $38.8 \mathrm{ppbv}$ ) and Hendrick et al. ${ }^{23}$ (2 ppbv at urban sites and 1.25 ppbv at suburban sites in Beijing). It could be seen from Fig. 4 that during the haze period at the urban site, the concentrations of $\mathrm{SO}_{2}, \mathrm{CO}, \mathrm{NO}, \mathrm{NO}_{2}$, $\mathrm{NO}_{x}$ and $\mathrm{PM}_{2.5}$ were enhanced 4.8, 4.2, 4.2, 4.0, 4.7 and 8.2 times, respectively, while concentrations of HONO were enhanced 3.8 times. For the suburban site, concentrations of $\mathrm{SO}_{2}, \mathrm{CO}, \mathrm{NO}, \mathrm{NO}_{2}, \mathrm{NO}_{x}$ and $\mathrm{PM}_{2.5}$ were enhanced 1.4, 2.3, 3.5, 3.4, 3.6 and 5.0 times, respectively, while the enhancement of HONO concentrations was only 1.8 times. This indicates that some connections lie between these gas pollutants and HONO with different extents, which may be associated with various processes.

Diurnal variations of the measured chemical species. To further understand the connections between the gas-phase species and the characteristics of HONO variations in the two areas, diurnal variation of HONO concentrations and other gas-phase species were averaged by the weather conditions. Fig. 5 shows the daily variations of gas pollutants during the two periods in both sites. In the urban site, the concentration of HONO during the haze period showed a morning peak at around 7:00 (3.00 ppbv on average). Then it began to decrease due to the increase of irradiance. After reaching a minimum ( $0.39 \mathrm{ppbv}$ on average) at around 15:00, it revived to $1.12 \mathrm{ppbv}$ at 20:00 and kept increasing to $1.86 \mathrm{ppbv}$ until 1:00. The concentrations of HONO then remained between 1.86-2.18 ppbv for the rest of the night. It should be noted that there was no evening peak of HONO concentrations during the evening traffic peak period. This may be covered by the cooperation of photolysis reduction and enhancement due to decreasing of 


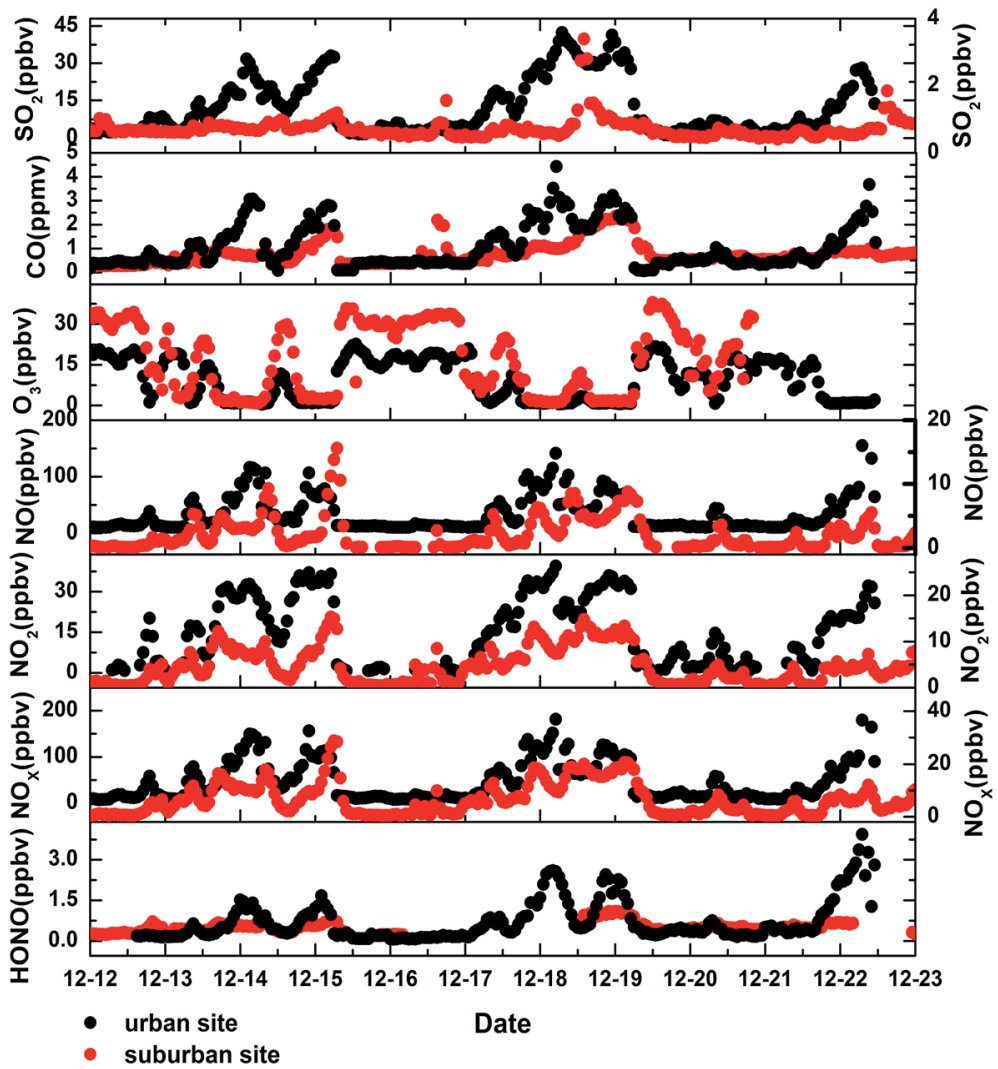

Fig. 3 Variation of gas species measured during the observation campaign at the urban site and suburban site (the black points show concentrations at the urban site, and red points show concentrations at the suburban site). The ordinate axes of $\mathrm{SO}_{2}, \mathrm{NO}, \mathrm{NO}_{2}$ and $\mathrm{NO}_{x}$ in the suburban site were adjusted and are shown on the right side.

boundary layer height. While during the non-haze period, HONO concentrations decreased and remained at a low level (0.21-0.32 ppbv) during both day and night except for the morning traffic peak period, when concentrations of HONO could rise to 0.43 ppbv. Additionally, HONO concentrations did not show significant differences between daytime and nighttime. In the suburban site, HONO concentration varied in a similar manner to its variation in the urban area. During the haze period, it reduced to $0.40 \mathrm{ppbv}$ around 13:00 and then rose to $0.72 \mathrm{ppbv}$ at around 20:00. For the rest of the night, HONO concentrations remained between $0.72-0.75$ ppbv until 6:00 in the morning. Unlike the variations during the haze period, HONO in the clean period showed two significant peaks in the traffic rush hour: one was of $0.52 \mathrm{ppbv}$ at around 9:00 and the other was of 0.56 ppbv at 20:00. However, during the rest of the day, HONO concentrations remained at a low level with a nighttime range of $0.37-0.49 \mathrm{ppbv}$ and a daytime range of 0.39-0.48 ppbv. After reaching the evening peak, HONO concentrations decreased and stayed at around $0.40 \mathrm{ppbv}$ until the next morning. This value was comparable to the minimum value $(0.39 \mathrm{ppbv})$ which appeared at 14:00. In general, the characteristics of HONO variations could be summarized as follows: 

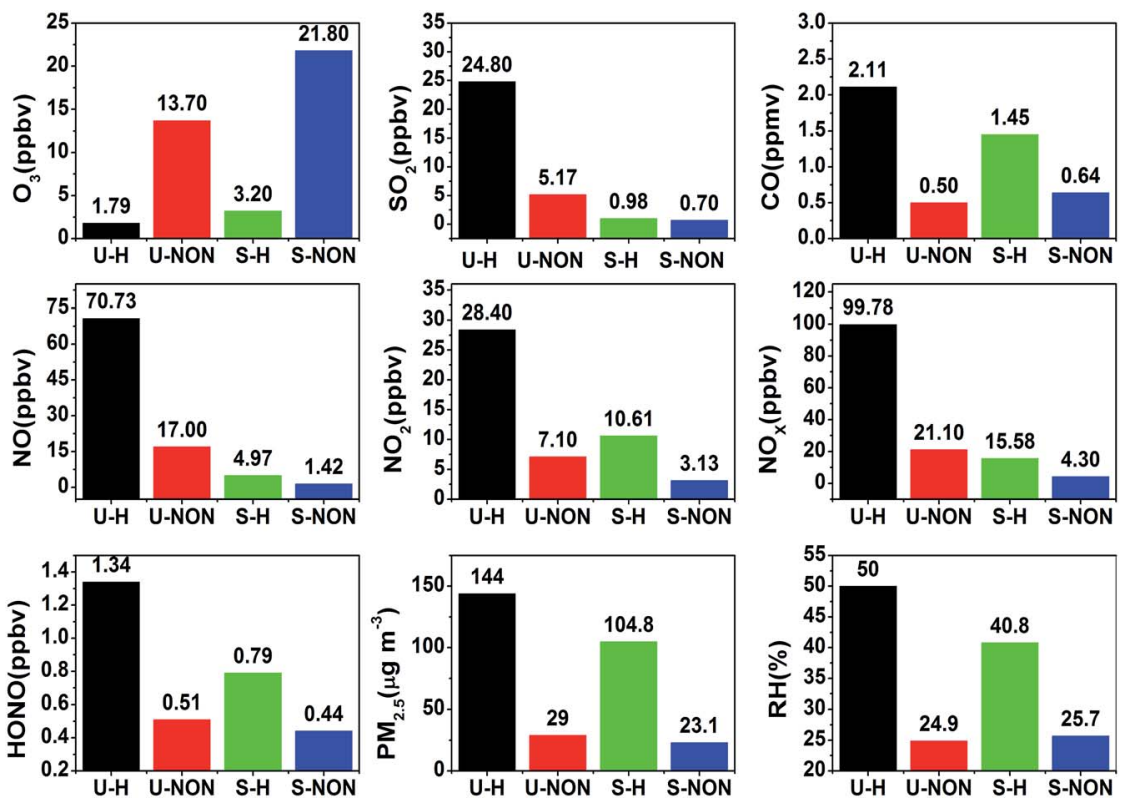

Fig. 4 Comparison of the average concentrations of gas-phase species as well as $P M_{2.5}$ and $\mathrm{RH}$ in urban and suburban sites during both haze and non-haze periods ( $\mathrm{U}-\mathrm{H}$ means urban with haze; U-NON means urban with non-haze; S-H means suburban with haze; SNON means suburban with non-haze).

First, HONO concentrations in haze conditions were higher than those in clean conditions, no matter whether in urban areas or suburban areas. However, differences of HONO concentrations between haze and clean conditions were much bigger in urban sites than suburban ones. Second, unlike the variation tendencies of the suburban site, which showed an "M" shape with peaks at 9:30 and 17:00 in both conditions, HONO concentrations only showed one peak at morning rush hour. This suggested that HONO concentrations were influenced by complicated factors.

For variations of other species, significant differences existed between the urban and suburban sites as well as between the haze and non-haze periods. However, the results were consistent with our previous studies and other studies. ${ }^{\mathbf{8 2 3 , 2 6 , 3 2}}$ In the urban site, variations during the haze period were rather different from those during the non-haze period. For instance, the maximum value of $\mathrm{O}_{3}$ concentrations was delayed to 15:00 from 13:00. Actually, concentrations of $\mathrm{SO}_{2}, \mathrm{CO}, \mathrm{NO}$ and $\mathrm{NO}_{x}$ in the non-haze period were so low that their diurnal variation characteristics were not obvious. However, they still showed morning peaks at around 8:00, and so did HONO. This indicated that the morning peak of $\mathrm{HONO}$ had some connection with $\mathrm{SO}_{2}, \mathrm{CO}, \mathrm{NO}$ and $\mathrm{NO}_{x}$. For the situation at the suburban site, during the haze period concentrations of $\mathrm{CO}$ and $\mathrm{NO}_{2}$ were higher in the night and kept decreasing with increasing sunlight intensity after dawn. Both of them reached a minimum at noon. $\mathrm{NO}$ and $\mathrm{NO}_{x}$ showed morning peaks around 8:00. Additionally, $\mathrm{SO}_{2}$ concentrations increased significantly at 14:00 with low concentrations during the whole day. During the 

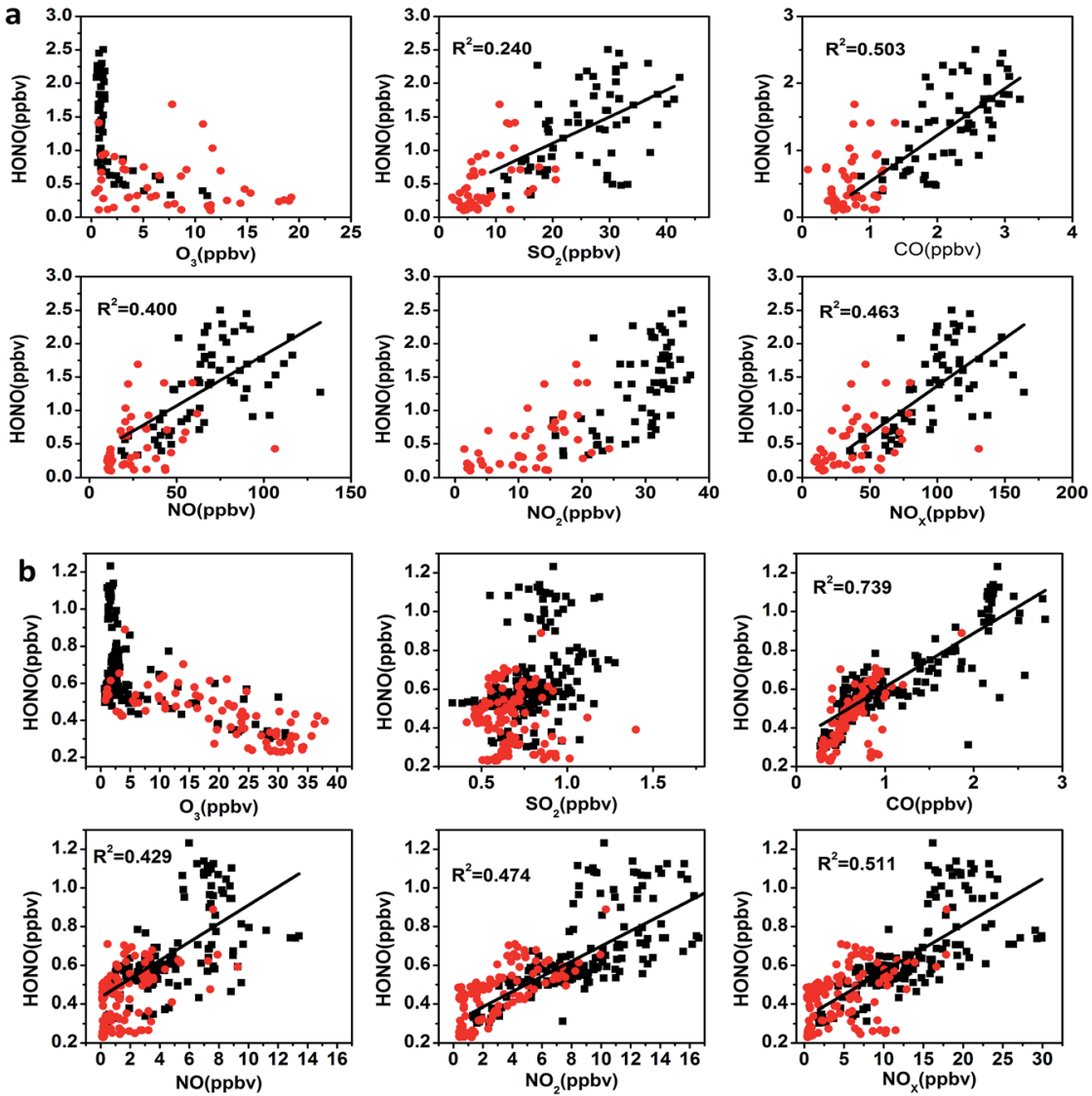

Fig. 6 (a) Correlation between $\mathrm{HONO}$ and $\mathrm{O}_{3}, \mathrm{SO}_{2}, \mathrm{CO}, \mathrm{NO}, \mathrm{NO}_{2}$ and $\mathrm{NO}_{x}$ during the haze period (black) and clean period (red) in the urban site. (b) Correlation between HONO and $\mathrm{O}_{3}, \mathrm{SO}_{2}, \mathrm{CO}, \mathrm{NO}, \mathrm{NO}_{2}$ and $\mathrm{NO}_{x}$ during the haze period (black) and clean period (red) in the suburban site.

those during the non-haze period. This indicated that the impacts of $\mathrm{CO}, \mathrm{NO}_{x}$ and other gases may be more effective in the non-haze period, which strengthens the complication of HONO sources. In the suburban area (Fig. 6(b)), obvious correlations existed for $\mathrm{HONO}$ with $\mathrm{CO}, \mathrm{NO}$ and $\mathrm{NO}_{x}$ during the haze period and HONO with $\mathrm{O}_{3}, \mathrm{CO}$ and $\mathrm{NO}_{2}$ during the non-haze period. No certain correlations existed for $\mathrm{HONO}$ with $\mathrm{SO}_{2}$ in both periods. These facts suggested that HONO formation processes were different depending on locations and weather conditions, and the formation pathways in the suburban area were more complicated.

In general, $\mathrm{CO}$ and NO are mainly linked with combustion processes like vehicle emissions and the burning of fossil fuels and biomass, which could be seen as primary emission processes. ${ }^{33-35}$ Meanwhile, $\mathrm{NO}_{2}$ and $\mathrm{O}_{3}$ are more likely come from secondary formations. ${ }^{36}$ In the urban site, the correlations of $\mathrm{CO}$ with $\mathrm{NO}$ and $\mathrm{NO}_{x}$ during the whole observation were all higher than 0.8 (Fig. S2 $\dagger$ ), which means these three gases have a good chance to come from the same sources, such as traffic emissions. ${ }^{34}$ Moreover, the distinction between 
environmental conditions at the observation sites would contribute to the correlation differences. Due to their distance from each other, the urban site is surrounded by dense traffic flows as well as human activities, while in the suburban area the train station, small factories, farmland and the Yanqi lake were all sources which made the environmental conditions complicated. As a result, though good correlations of $\mathrm{HONO}$ with $\mathrm{CO}, \mathrm{NO}$ and $\mathrm{NO}_{x}$ appeared in both urban and suburban sites, the sources were different. In urban areas it may be caused by mobile sources ${ }^{22}$ like vehicle emissions, while in suburban areas it may be caused by a combination of fossil fuel burning, biomass burning, vehicle emissions and other combustion and emission processes.

Direct emission. Apparently, HONO in the urban area was greatly affected by direct emissions. Moreover, due to the complicated emission sources and environmental conditions, HONO concentrations in the suburban area were much more associated with secondary formation processes.

To evaluate HONO amounts from direct emissions in the atmosphere, a factor of 0.008 was supported by Kurtenbach et $a{ }^{11}$ and is widely accepted in most observation studies. Therefore, 0.008 was used to calculate the HONO concentrations from direct emissions $\left(\mathrm{HONO}_{\mathrm{emission}}\right)$ by the formula: $\left[\mathrm{HONO}_{\mathrm{emission}}\right]=$ $\left[\mathrm{NO}_{x}\right] \times 0.008 .{ }^{8}$ Where, $\left[\mathrm{HONO}_{\text {emission }}\right]$ represents HONO concentrations from direct emissions, and $\left[\mathrm{NO}_{x}\right]$ represents concentrations of $\mathrm{NO}_{x}$.

The mean values of calculated $\mathrm{HONO}_{\text {emission }}$ were 0.37 and $0.06 \mathrm{ppbv}$, respectively, which contributed $48.8 \%$ and $10.3 \%$ of HONO concentrations in the urban and suburban sites. The results were comparable with contributions of $49.7 \%$ when $\mathrm{NO}_{x}$ concentrations were $266 \mathrm{ppbv}$ in urban Beijing ${ }^{22}$ and $8.5 \%$ with $\mathrm{NO}_{x}$ concentrations of $11.9 \mathrm{ppbv}$ obtained at the same observation sites in our previous work. ${ }^{28}$ Moreover, the contributions of direct emissions in both sites were enhanced during the haze period. However, at the urban site, the contribution of direct emissions was higher at up to $40.4 \%$ with $\mathrm{NO}_{x}$ concentrations of $99.8 \mathrm{ppbv}$ even during the non-haze period. This suggested direct emissions would be the major source of HONO in urban areas, and haze conditions would aggravate this contribution. On the other hand, there would be other important processes influencing HONO concentrations in suburban areas.

\section{Heterogeneous conversion from $\mathrm{NO}_{2}$}

$\mathrm{HONO} / \mathrm{NO}_{2}$ ratio and $\mathrm{NO}_{2}$ conversion rates. It is well-accepted that HONO could be formed on wet surfaces by the heterogeneous conversion of $\mathrm{NO}_{2} \cdot{ }^{14-16}$ The $\mathrm{HONO} / \mathrm{NO}_{2}$ ratio is usually used to evaluate the heterogeneous conversion efficiency of $\mathrm{NO}_{2}$ to $\mathrm{HONO}$, assuming all of the $\mathrm{HONO}$ comes from $\mathrm{NO}_{2}$ conversion. ${ }^{8,37,38}$ However, this value would overestimate the conversion efficiency if the contributions from direct emissions and homogeneous production were large. ${ }^{3,10,32,39}$ Hence, corrected HONO concentrations $\left(\mathrm{HONO}_{\text {corr }}\right)$, which had contributions from direct emissions subtracted, were used to study the heterogeneous reactions instead of the observed ones.

Fig. 7 shows the variations of $\mathrm{HONO}_{\text {corr }} / \mathrm{NO}_{2}$ during the haze and non-haze periods from the urban and suburban sites. Wind speeds were lower than $1.0 \mathrm{~m}$ $\mathrm{s}^{-1}$ during these selected periods. The low $\mathrm{HONO}_{\text {corr }}$ concentrations showed mainly contributions of direct emissions. The variations between the two sites showed rather different tendencies. In the urban site, $\mathrm{HONO}_{\text {corr }} / \mathrm{NO}_{2}$ reached its 
which reflected higher conversion rates in suburban sites and during the nonhaze period. The $\mathrm{NO}_{2}-\mathrm{HONO}$ conversion rate was affected by several factors including the environment, particle concentrations and aerosol surfaces, ${ }^{\mathbf{1 4 , 4 0}}$ it is better to consider these parameters when exploring the heterogeneous conversion of $\mathrm{NO}_{2}$.

Impact of $\mathbf{P M}_{2.5}$ and $\mathbf{R H}$. The heterogeneous conversion of $\mathrm{NO}_{2}$ to $\mathrm{HONO}$ could occur on various types of surfaces as well as aerosols with the extinction of water, thus the impact of aerosol surfaces and surface water on the $\mathrm{NO}_{2}$ conversion rates should be focused on. As already shown by several lab studies, the conversion was first order in $\mathrm{NO}_{2}{ }^{40}$ and in functions of relative humidity ${ }^{18}$ and surface area to volume ratio $(S / V) .{ }^{\mathbf{1 4}}$

Daytime data were ignored in order to avoid the influence of photolysis. HONO concentrations were corrected and denoted as $\mathrm{HONO}_{\text {corr }}$, as well. Correlations of $\mathrm{HONO}_{\text {corr }}$ and $\mathrm{HONO}_{\text {corr }} / \mathrm{NO}_{2}$ ratios with $\mathrm{PM}_{2.5}$ and $\mathrm{RH}$ are illustrated in Fig. 8. This showed that the relationship between $\mathrm{HONO}_{\text {corr }} / \mathrm{NO}_{2}$ and $\mathrm{PM}_{2.5}$ was obscure, especially when $\mathrm{PM}_{2.5}$ concentrations were higher than $160 \mu \mathrm{g} \mathrm{m}^{-3}$. However, the correlation coefficient of $\mathrm{HONO}_{\text {corr }}$ with $\mathrm{PM}_{2.5}$ (0.514) still showed some promotion effects. Heterogeneous conversion of $\mathrm{NO}_{2}$ would occur on ground surfaces as well as aerosols, the higher surface density of ground was often supposed to play a main role in HONO formation over the aerosol surface. While, our measurement results showed that compared to the ground surface the high particulate matter concentrations during the haze period would promote the heterogeneous conversion of $\mathrm{NO}_{2}$. Similarly, the correlations of $\mathrm{HONO}_{\text {corr }}$ and $\mathrm{HONO}_{\text {corr }} / \mathrm{NO}_{2}$ with $\mathrm{RH}$ showed $\mathrm{RH}$ would promote the conversion of HONO, though
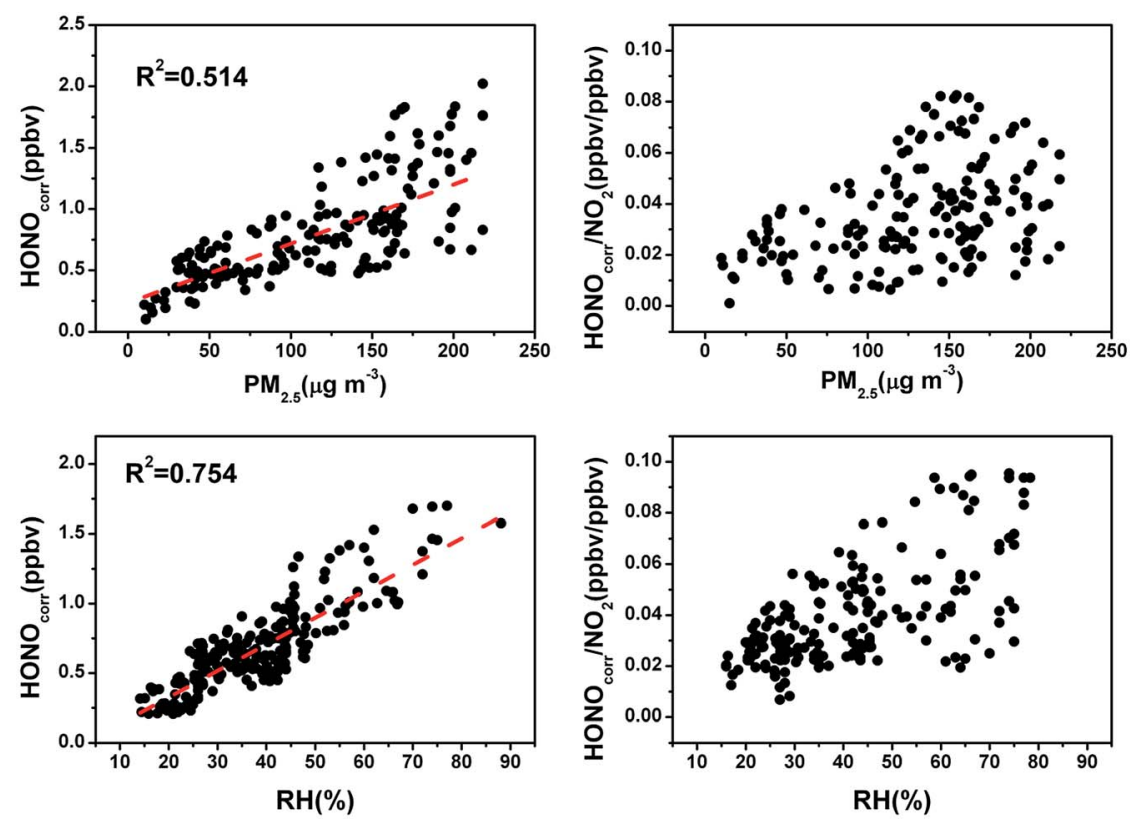

Fig. 8 Correlations of $\mathrm{HONO}_{\text {corr }}$ and $\mathrm{HONO}_{\text {corr }} / \mathrm{NO}_{2}$ ratios with $\mathrm{PM}_{2.5}$ (top) and correlations of $\mathrm{HONO}_{\text {corr }}$ and $\mathrm{HONO}_{\text {corr }} / \mathrm{NO}_{2}$ ratios with $\mathrm{RH}$ (bottom). 


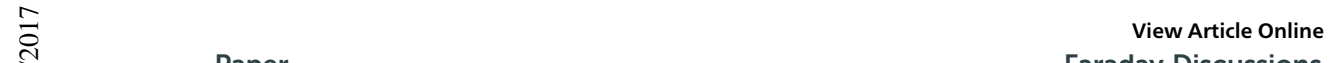

$\mathrm{HONO}_{\text {corr }} / \mathrm{NO}_{2}$ ratios increased with growing $\mathrm{RH}$ and decreased when $\mathrm{RH}$ was higher than $60 \%$. Additionally, the good correlations of $\mathrm{HONO} / \mathrm{NO}_{2}$ with particles ${ }^{25,41,42}$ and $\mathrm{RH}^{18,25}$ have been shown in many previous studies.

However, measurements by Kleffmann et al. ${ }^{38}$ and Stutz et al. ${ }^{18}$ showed weak aerosol impact on HONO formation, and this suggestion was supported by laboratory studies on soot and organic particles. As boundary layer height (BLH) decreased in the nighttime, this led to the increasing of the $S / V$ ratio and concentrations of other gas-phase pollutants. ${ }^{37,43}$ Meanwhile, $\mathrm{RH}$ would increase as well due to the decreasing of temperature. Therefore, the good correlations will be affected by these factors. And the impacts of aerosols and RH vary with environmental conditions and are still in debate. Given this measurement only provides a rough study on the impacts of particulate matter, gradient measurements of $\mathrm{HONO}$ with $\mathrm{NO}_{2}$ and aerosol concentrations are highly recommended to prove the possible impacts of aerosols on HONO formation. ${ }^{43}$

The impacts of gas phase reaction between NO and OH. As discussed above, the known sources of HONO include direct emissions, homogeneous formation and heterogeneous conversions. Therefore, the impacts of reaction between NO and $\mathrm{OH}$ should not be neglected. The homogeneous production of nocturnal $\mathrm{HONO}$ was dominated by the reaction $\mathrm{NO}+\mathrm{OH} \rightarrow \mathrm{HONO}\left(k_{\mathrm{NO}+\mathrm{OH}}=7.4 \times 10^{-12}\right.$ $\mathrm{cm}^{3}$ molecules $\left.{ }^{-1} \mathrm{~s}^{-1}\right)$ and $\mathrm{HONO}+\mathrm{OH} \rightarrow \mathrm{NO}_{2}+\mathrm{H}_{2} \mathrm{O}\left(k_{\mathrm{HONO}+\mathrm{OH}}=6.0 \times 10^{-12}\right.$ $\mathrm{cm}^{3}$ molecules ${ }^{-1} \mathrm{~s}^{-1}$ ), and the net HONO homogeneous production could be calculated by: $:^{3,8,38}$

$$
P_{\text {net }}=k_{\mathrm{OH}+\mathrm{NO}}[\mathrm{OH}][\mathrm{NO}]-k_{\mathrm{OH}+\mathrm{HONO}}[\mathrm{OH}][\mathrm{HONO}]
$$

where [ ] represents the concentrations of gases. For comparison, a nighttime $\mathrm{OH}$ concentration of $1 \times 10^{6}$ molecules per $\mathrm{cm}^{3}$ was assumed to represent the measured ones in both urban and suburban areas as supported by previous studies $^{44-47}$ in Chinese urban areas during winter time.

In the urban site, the value of $P_{\text {net }}$ was tightly connected with the NO concentration. When nocturnal NO was in the range of 52.7 to $141.4 \mathrm{ppbv}$ in the haze period, the mean value of $P_{\text {net }}$ could be $2.02 \mathrm{ppbv} \mathrm{h}^{-1}$ (Table 2). This showed the production of net $\mathrm{NO}+\mathrm{OH}$ reaction would supply $59.50 \%$ of the $\mathrm{HONO}_{\text {corr }}$ enhancement on average. While in the non-haze period, NO concentrations varied little with an average value of $12.33 \mathrm{ppbv}$, leading to a mean $P_{\text {net }}$ of 0.32 $\mathrm{ppbv} \mathrm{h}^{-1}$. However, it still provided $43.92 \%$ HONO enhancement on average. In the case of the suburban area, the nocturnal NO concentration was too low to

Table 2 The nocturnal HONO budget during haze and non-haze periods in the urban and suburban sites

\begin{tabular}{llllll}
\hline Location & Time period & $P_{\text {net }}^{a}$ & $P_{\text {heter }}$ & $P_{\text {heter }} /\left[\mathrm{NO}_{2}\right]$ & $C_{\text {HONO }}$ \\
\hline Urban & Haze & 2.02 & 0.070 & 0.002 & 0.005 \\
Urban & Non-haze & 0.32 & 0.013 & 0.010 & 0.013 \\
Suburban & Haze & 0.0051 & 0.058 & 0.005 & 0.008 \\
Suburban & Non-haze & 0.0023 & 0.025 & 0.019 & 0.016
\end{tabular}

${ }^{a}$ Units of $P_{\text {net }}, P_{\text {heter }}, P_{\text {heter }} /\left[\mathrm{NO}_{2}\right]$ and $C_{\text {HONO }}$ are $\mathrm{ppbv} \mathrm{h}^{-1}, \mathrm{ppbv} \mathrm{h}^{-1}, \mathrm{~h}^{-1}$ and $\mathrm{h}^{-1}$, respectively. 


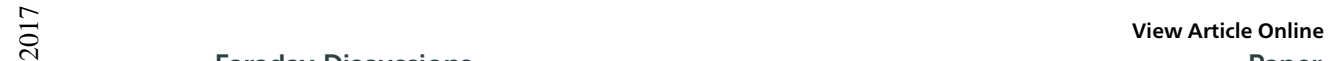

support HONO increase with a mean $P_{\text {net }}$ value of $0.026 \mathrm{ppbv}^{-1}$, which was an order of magnitude lower than the urban site. Even in the haze period, when NO concentrations increased from $1.2 \mathrm{ppbv}$ to $6.4 \mathrm{ppbv}$, the $P_{\text {net }}$ value was only 0.0051 $\mathrm{ppbv} \mathrm{h}^{-1}$ on average. This indicated that the effects of homogeneous reactions did not work in the suburban area, and heterogeneous formation may be a critical supplement to nocturnal HONO concentrations, in light of the low contribution of direct emissions, which has been discussed above.

It is well accepted that the major HONO removal pathway is dry deposition during the night. HONO removal by dry deposition $\left(L_{\mathrm{dep}}\right)$ can be calculated by $V_{\mathrm{d}}$ $\times[\mathrm{HONO}] / H$, where $V_{\mathrm{d}}$ represents dry deposition velocity of HONO and $H$ is the mixing height. $V_{\mathrm{d}}$ was assumed to be $2.0 \mathrm{~cm} \mathrm{~s}^{-1}$ as used by Harrison et al. ${ }^{47}$ Because the wind speed was low, horizontal and vertical transport could be neglected. The $L_{\mathrm{dep}}$ values were supposed to be 0.035 and $0.015 \mathrm{ppbv} \mathrm{h}^{-1}$ on average for the haze period and non-haze period, respectively. This means that least $0.070,0.013,0.058$ and $0.025 \mathrm{ppbv} \mathrm{h}^{-1}$ of heterogeneous production was needed after subtracting the contributions from direct emissions in the haze period in the urban area, non-haze period in the urban area, haze period in the suburban area and non-haze period in the suburban area, respectively. The results were in agreement with the $C_{\text {HONO }}$ values of $0.005,0.013,0.008$ and $0.016 \mathrm{~h}^{-1}$ calculated above.

Take the nights of Dec 18 and Dec 19 for example:

In the urban site, the integrated $P_{\text {net }}$ values from 20:00 to 2:00 were $0.417 \mathrm{ppbv}$ with $\mathrm{OH}$ concentrations of $1.0 \times 10^{6}$ molecules per $\mathrm{cm}^{3}$, which was $69.14 \%$ of the measured increase of HONO after subtracting direct emissions (from $0.74 \mathrm{ppbv}$ to 1.47 ppbv) for the night of Dec 18 (Fig. 9). During the night of Dec 19, the low NO concentrations could only provide a $P_{\text {net }}$ of $0.292 \mathrm{ppbv} \mathrm{h}^{-1}$ with an integrating area of $0.048 \mathrm{ppbv}$, which was $43.67 \%$ of the HONO increase (0.21-0.32 ppbv). Thus, the heterogeneous productions of these two nights were at least 0.032 and
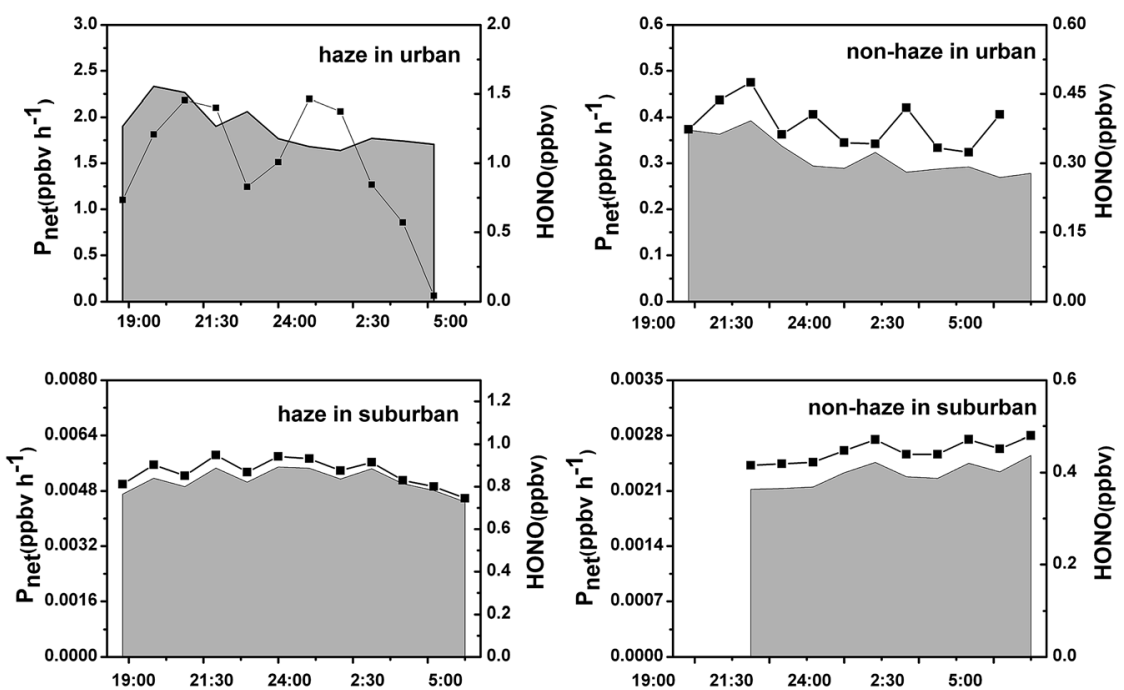

Fig. 9 Variations patterns of $P_{\text {net }}$ and $P_{\text {heter }}$ in the night of Dec 18 (haze period) and Dec 19 (non-haze) period in urban and suburban sites. 
$0.013 \mathrm{~h}^{-1}$, respectively. In the same way, the calculated heterogeneous production $P_{\text {heter }}$ was 0.058 and $0.025 \mathrm{ppbv}^{-1}$ for haze and non-haze periods in the suburban area. The heterogeneous production rates were almost 10 times higher than net homogeneous production. This suggested that the net production by homogeneous reactions could be dominant for the nocturnal increase of HONO in the urban site while production by heterogeneous reactions would be the major source of HONO in the suburban site.

In summary, the nocturnal HONO formation mechanisms in urban and suburban areas were different. The contributions of direct emissions were $48.8 \%$ and $10.3 \%$ in urban and suburban sites, respectively. Moreover, due to the rather high NO and $\mathrm{NO}_{x}$ concentrations in the urban area, the production of homogeneous reactions during both haze and non-haze periods were unneglectable with production rates of 2.02 and $0.32 \mathrm{ppbv} \mathrm{h}^{-1}$, respectively. In the case of the suburban area, the concentrations of $\mathrm{NO}$ and $\mathrm{NO}_{x}$ were so low as to make the contributions of homogeneous production and direct emissions neglectable, which led to the heterogeneous reactions becoming the major source of HONO. Considering the removal of HONO by dry deposition, the heterogeneous production rates were calculated to be at least $0.070,0.013,0.058$ and $0.025 \mathrm{ppbv}$ $\mathrm{h}^{-1}$ for the haze period of the urban area, non-haze period of the urban area, haze period of the suburban area and non-haze period of the suburban area, respectively.

\section{Conclusions}

Measurements of HONO and other pollutants were performed in urban and suburban sites to explore the HONO formation mechanisms from December 12 to December 22 in Beijing. The measurements included haze and non-haze processes in both urban and suburban sites.

The hourly-averaged concentrations of $\mathrm{HONO}, \mathrm{CO}, \mathrm{SO}_{2}, \mathrm{O}_{3}, \mathrm{NO}, \mathrm{NO}_{2}$ and $\mathrm{NO}_{x}$ in the haze period were $0.86 \mathrm{ppbv}, 1.54 \mathrm{ppmv}, 12.0 \mathrm{ppbv}, 9.4 \mathrm{ppbv}, 33.1 \mathrm{ppbv}, 16.5$ ppbv, and $49.6 \mathrm{ppbv}$, respectively, much higher than concentrations in the suburban area (0.52 ppbv, $1.05 \mathrm{ppmv}, 0.8 \mathrm{ppbv}, 14.4 \mathrm{ppbv}, 3.6 \mathrm{ppbv}, 6.5 \mathrm{ppbv}$, and $11.1 \mathrm{ppbv}$ ). Moreover, HONO concentrations during the haze period were 2.63 times higher than in the non-haze period in the urban site, and 1.80 times higher during haze in the suburban site. Correlation studies showed HONO was highly connected with $\mathrm{CO}, \mathrm{NO}_{x}$, and $\mathrm{SO}_{2}$, and the correlations varied with the locations and the environmental conditions. The results indicated that direct emission was the main factor affecting correlations of HONO with $\mathrm{CO}$ and $\mathrm{NO}_{x}$ in the urban site. Moreover, studies of $\mathrm{HONO}_{\text {emissions }}$ (HONO from direct emissions) showed mean direct emissions contributions of $48.8 \%$ in the urban area, but were $10.3 \%$ in the suburban area, reflecting a less significant contribution.

Additionally, to evaluate the nocturnal heterogeneous conversion of $\mathrm{NO}_{2}$, both $\mathrm{HONO}_{\text {corr }} / \mathrm{NO}_{2}$ ratios and $C_{\mathrm{HONO}}$ rates were calculated. The results agreed with each other and showed that higher $\mathrm{HONO}_{\text {corr }} / \mathrm{NO}_{2}$ ratios indicated a higher $\mathrm{NO}_{2}$ conversion efficiency in the non-haze period in both areas. Moreover, the correlations of $\mathrm{HONO}_{\text {corr }} / \mathrm{NO}_{2}$ vs. $\mathrm{RH}$ and $\mathrm{HONO}_{\text {corr }} / \mathrm{NO}_{2}$ vs. $\mathrm{PM}_{2.5}$ concentrations showed RH and particle concentrations may be important factors affecting the $\mathrm{NO}_{2}$ conversion. $\mathrm{HONO}_{\text {corr }} / \mathrm{NO}_{2}$ ratios were proportional with $\mathrm{RH}$ and $\mathrm{PM}_{2.5}$ concentrations when $\mathrm{RH}$ was below $60 \%$ and $\mathrm{PM}_{2.5}$ concentrations were lower 
than $160 \mu \mathrm{g} \mathrm{m}^{-3}$. However, $\mathrm{HONO}_{\text {corr }} / \mathrm{NO}_{2}$ ratios fell down when $\mathrm{RH}$ was higher than $60 \%$ and $\mathrm{PM}_{2.5}$ concentrations were higher than $160 \mu \mathrm{g} \mathrm{m} \mathrm{m}^{-3}$. Finally, the nocturnal productions from homogeneous reactions and heterogeneous reactions were compared. Due to the extremely high concentrations of NO in urban areas, the contributions of homogeneous reaction production would be significant in both haze and non-haze periods. While in the suburban area, the production from heterogeneous conversion was the major contributor, about 10 times higher than net homogeneous production in haze and non-haze periods.

\section{Acknowledgements}

This project was supported by the Strategic Priority Research Program (B) of the Chinese Academy of Sciences (Grant No. XDB05010400), and the National Natural Science Foundation of China (Contract No. 41475114, 21477134).

\section{References}

1 K. D. Lu, F. Rohrer, F. Holland, H. Fuchs, B. Bohn, T. Brauers, C. C. Chang, R. Häseler, M. Hu, K. Kita, Y. Kondo, X. Li, S. R. Lou, S. Nehr, M. Shao, L. M. Zeng, A. Wahner, Y. H. Zhang and A. Hofzumahaus, Atmos. Chem. Phys., 2012, 12, 1541-1569.

2 J. Kleffmann, ChemPhysChem, 2007, 8, 1137-1144.

3 B. Alicke, U. Platt and J. Stutz, J. Geophys. Res.: Atmos., 2002, 107, DOI: 10.1029/ 2000JD000075.

4 K. Acker, D. Möller, W. Wieprecht, F. X. Meixner, B. Bohn, S. Gilge, C. PlassDülmer and H. Berresheim, Geophys. Res. Lett., 2006, 33, L02809.

5 B. Aumont, F. Chervier and S. Laval, Atmos. Environ., 2003, 37, 487-498.

6 B. Alicke, A. Geyer, A. Hofzumahaus, F. Holland, S. Konrad, H. W. Pätz, J. Schäfer, J. Stutz, A. Volz-Thomas and U. Platt, J. Geophys. Res.: Atmos., 2003, 108, 8247.

7 V. Michoud, A. Colomb, A. Borbon, K. Miet, M. Beekmann, M. Camredon, B. Aumont, S. Perrier, P. Zapf, G. Siour, W. Ait-Helal, C. Afif, A. Kukui, M. Furger, J. C. Dupont, M. Haeffelin and J. F. Doussin, Atmos. Chem. Phys, 2014, 14, 2805-2822.

8 X. Li, T. Brauers, R. Häseler, B. Bohn, H. Fuchs, A. Hofzumahaus, F. Holland, S. Lou, K. D. Lu, F. Rohrer, M. Hu, L. M. Zeng, Y. H. Zhang, R. M. Garland, H. Su, A. Nowak, A. Wiedensohler, N. Takegawa, M. Shao and A. Wahner, Atmos. Chem. Phys., 2012, 12, 1497-1513.

9 J. Kleffmann, T. Gavriloaiei, A. Hofzumahaus, F. Holland, R. Koppmann, L. Rupp, E. Schlosser, M. Siese and A. Wahner, Geophys. Res. Lett., 2005, 32, L05818.

10 G. Lammel and J. N. Cape, Chem. Soc. Rev., 1996, 25, 361-369.

11 R. Kurtenbach, K. H. Becker, J. A. G. Gomes, J. Kleffmann, J. C. Lörzer, M. Spittler, P. Wiesen, R. Ackermann, A. Geyer and U. Platt, Atmos. Environ., 2001, 35, 3385-3394.

12 T. W. Kirchstetter, R. A. Harley and D. Littlejohn, Environ. Sci. Technol., 1996, 30, 2843-2849.

13 C. George, R. S. Strekowski, J. Kleffmann, K. Stemmler and M. Ammann, Faraday Discuss., 2005, 130, 195-210. 
14 B. J. Finlayson-Pitts, L. M. Wingen, A. L. Sumner, D. Syomin and K. A. Ramazan, Phys. Chem. Chem. Phys., 2003, 5, 223-242.

15 J. G. Calvert, G. Yarwood and A. M. Dunker, Res. Chem. Intermed., 1994, 20, 463-502.

16 M. Ammann, M. Kalberer, D. T. Jost, L. Tobler, E. Rössler, D. Piguet, H. W. Gaggeler and U. Baltensperger, Nature, 1998, 395, 157-160.

17 V. H. Grassian, Int. Rev. Phys. Chem., 2001, 20, 467-548.

18 J. Stutz, B. Alicke, R. Ackermann, A. Geyer, S. H. Wang, A. B. White, E. J. Williams, C. W. Spicer and J. D. Fast, J. Geophys. Res.: Atmos., 2004, 109, D03307.

19 K. Stemmler, M. Ammann, C. Donders, J. Kleffmann and C. George, Nature, 2006, 440, 195-198.

20 R. Broske, J. Kleffmann and P. Wiesen, Atmos. Chem. Phys., 2003, 3, 469-474.

21 M. Sörgel, E. Regelin, H. Bozem, J. M. Diesch, F. Drewnick, H. Fischer, H. Harder, A. Held, Z. Hosaynali-Beygi, M. Martinez and C. Zetzsch, Atmos. Chem. Phys., 2011, 11, 10433-10447.

22 F. Spataro, A. Ianniello, G. Esposito, I. Allegrini, T. Zhu and M. Hu, Sci. Total Environ., 2013, 447, 210-224.

23 F. Hendrick, J. F. Müller, K. Clémer, P. Wang, M. De Maziere, C. Fayt, C. Gielen, C. Hermans, J. Z. Ma, G. Pinardi, T. Stavrakou, T. Vlemmix and M. van Roozendael, Atmos. Chem. Phys., 2014, 14, 765-781.

24 M. Qin, P. H. Xie, W. Q. Liu, A. Li, K. Dou, W. Fang, H. G. Liu and W. J. Zhang, J. Environ. Sci., 2006, 18, 69-75.

25 M. Qin, P. Xie, H. Su, J. Gu, F. Peng, S. Li, L. Zeng, J. Liu, W. Liu and Y. Zhang, Atmos. Environ., 2009, 43, 5731-5742.

26 S. Wang, R. Zhou, H. Zhao, Z. Wang, L. Chen and B. Zhou, Atmos. Environ., 2013, 77, 718-724.

27 S. Hou, S. Tong, M. Ge and J. An, Atmos. Environ., 2016, 124, 199-206.

28 S. R. Tong, S. Q. Hou, Y. Zhang, B. W. Chu, Y. C. Liu, H. He, P. S. Zhao and M. F. Ge, Sci. China: Chem., 2015, 58, 1393-1402.

29 G. Huang, X. L. Zhou, G. H. Deng, H. C. Qiao and K. Civerolo, Atmos. Environ., 2002, 36, 2225-2235.

30 J. Kleffmann, J. C. Lörzer, P. Wiesen, C. Kern, S. Trick, R. Volkamer, M. Rodenas and K. Wirtz, Atmos. Environ., 2006, 40, 3640-3652.

31 J. Heland, J. Kleffmann, R. Kurtenbach and P. Wiesen, Environ. Sci. Technol., 2001, 35, 3207-3212.

32 H. Su, Y. F. Cheng, P. Cheng, Y. H. Zhang, S. Dong, L. M. Zeng, X. Wang, J. Slanina, M. Shao and A. Wiedensohler, Atmos. Environ., 2008, 42, 6219-6232.

33 M. Levy, R. Y. Zhang, J. Zheng, A. L. Zhang, W. Xu, M. Gomez-Hernandez, Y. Wang and E. Olaguer, Atmos. Environ., 2014, 94, 231-240.

34 J. Quan, X. Tie, Q. Zhang, Q. Liu, X. Li, Y. Gao and D. Zhao, Atmos. Environ., 2014, 88, 83-89.

35 Y. L. Sun, Q. Jiang, Z. F. Wang, P. Q. Fu, J. Li, T. Yang and Y. Yin, J. Geophys. Res.: Atmos., 2014, 119, 4380-4398.

36 K. D. Lu, Y. H. Zhang, H. Su, T. Brauers, C. C. Chou, A. Hofzumahaus, S. C. Liu, K. Kita, Y. Kondo, M. Shao, A. Wahner, J. L. Wang, X. S. Wang and T. Zhu, J. Geophys. Res.: Atmos., 2010, 115, 18.

37 Y. Yu, B. Galle, A. Panday, E. Hodson, R. Prinn and S. Wang, Atmos. Chem. Phys., 2009, 9, 6401-6415. 


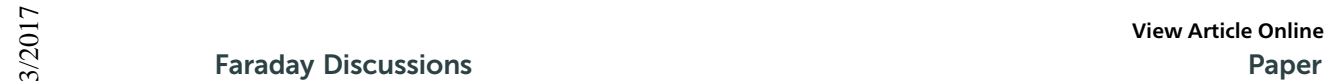

38 J. Kleffmann, R. Kurtenbach, J. Lörzer, P. Wiesen, N. Kalthoff, B. Vogel and H. Vogel, Atmos. Environ., 2003, 37, 2949-2955.

39 A. Febo, C. Perrino and M. Cortiello, Atmos. Environ., Part A, 1993, 27, 17211728.

40 J. Kleffmann, K. H. Becker and P. Wiesen, Atmos. Environ., 1998, 32, 27212729.

41 J. L. An, W. Zhang and Y. Qu, Atmos. Environ., 2009, 43, 3454-3459.

42 S. S. Park, S. B. Hong, Y. G. Jung and J. H. Lee, Atmos. Environ., 2004, 38, $293-$ 304.

43 N. Hao, B. Zhou, D. Chen and L.-m. Chen, J. Environ. Sci., 2006, 18, 910-915.

44 J. P. Pinto, J. Dibb, B. H. Lee, B. Rappenglück, E. C. Wood, M. Levy, R. Y. Zhang, B. Lefer, X. R. Ren, J. Stutz, C. Tsai, L. Ackermann, J. Golovko, S. C. Herndon, M. Oakes, Q. Y. Meng, J. W. Munger, M. Zahniser and J. Zheng, J. Geophys. Res.: Atmos., 2014, 119, 5583-5601.

45 K. D. Lu, A. Hofzumahaus, F. Holland, B. Bohn, T. Brauers, H. Fuchs, M. Hu, R. Häseler, K. Kita, Y. Kondo, X. Li, S. R. Lou, A. Oebel, M. Shao, L. M. Zeng, A. Wahner, T. Zhu, Y. H. Zhang and F. Rohrer, Atmos. Chem. Phys., 2013, 13, 1057-1080.

46 X. Ren, H. Gao, X. Zhou, J. D. Crounse, P. O. Wennberg, E. C. Browne, B. W. LaFranchi, R. C. Cohen, M. McKay, A. H. Goldstein and J. Mao, Atmos. Chem. Phys., 2010, 10, 6283-6294.

47 R. M. Harrison, J. D. Peak and G. M. Collins, J. Geophys. Res.: Atmos., 1996, 101, 14429-14439. 